\title{
Theologie als (her)interpretatie: Zesentwintig overwegingen
}

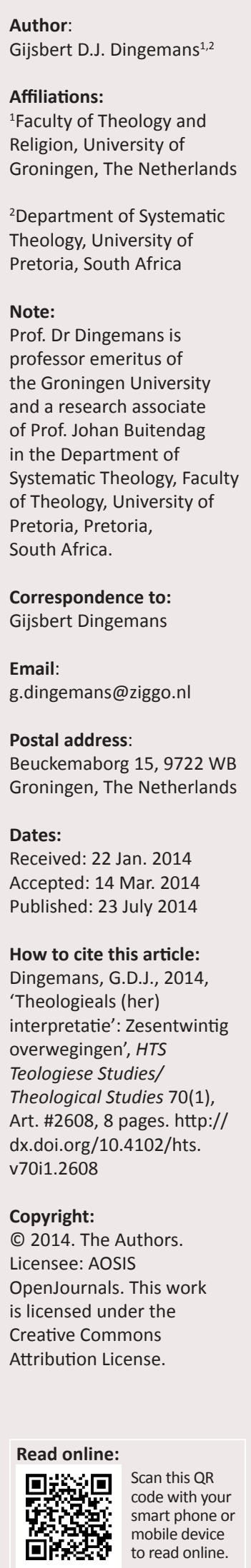

Theology as (re)interpretation: Twenty-six considerations. The article consists of 26 points of reflection by means of which the nature of theological discourse is considered as a hermeneutical process. These indicators cover aspects such as the relationship between the natural sciences and religious thinking; hermeneutics; philosophy; ultimacy; symbolic meaningfulness; Old Testament roots; historical Jesus; Christological dogmatics; creation and Spirit; kenosis; and social concern. The article concludes in its last reflection with the claim that plurality in both religious discourse and ecclesiastical structures is the challenge for theology, so as to remain relevant in the present-day scientific discourse and religiosity and to be obedient to the vocation of Jesus.

\section{Religie als respons Overweging 1}

Wetenschap, techniek, politiek, economie, ethiek, kunst, recht (wetgeving) en filosofie, maar ook religie, kerkvorming en theologie zijn mensenwerk. Ze zijn een menselijke interpretatie, ordening van en reactie op de indruk die de verscheidenheid van de buitenwereld (de zogeheten 'werkelijkheid') op ons maakt.

Natuurwetenschap en techniek brengen de tastbare en zintuiglijk ervaarbare werkelijkheid in kaart en proberen die te verklaren met gebruikmaking van eenduidige mathematische formules en wetmatigheden en zelfs aan te passen aan onze leefwijze. Ze moeten zich verantwoorden tegenover een wereldwijd forum van gevestigde wetenschappelijke interpretatietheorieën ook als ze die trachten te doorbreken - en ze moeten vanzelfsprekend hun gegevens (data) kunnen verifiëren.

De menswetenschappen (sociologie, psychologie), economie, bedrijfskunde en zo meer, berusten op waarnemingen in de samenleving en zoeken naar samenhangen en wetmatigheid daarin. Ze dienen herkenbare, relevante en vooral werkzame theorieën te ontwikkelen voor de samenleving op grond van algemeen toegankelijke gegevens (feiten).

Ethiek, recht, kunst, filosofie, theologie en religie richten zich niet alleen op de zintuiglijk ervaarbare werkelijkheid, maar houden ook rekening met het totaal van de werkelijkheidservaring en de grenzen daarvan. Ze moeten zich verantwoorden tegenover gevestigde tradities, de consistentie van hun opvattingen, beproefde waardepatronen en de plausibiliteit van een (liefst zo breed mogelijk) gedeelde ervaring - ook als ze die willen doorbreken en veranderen.

Religie en filosofie (levensbeschouwing) zijn meerduidige interpretatieve ontwerpen die een totaalbeeld van de werkelijkheid en het leven proberen te geven en in het bijzonder rekening houden met de 'ondoorgrondelijke' aspecten of de 'geheimenissen' van de werkelijkheid. Ze zijn gericht op de totaliteit en de samenhang van de werkelijkheid en zin en doel van het leven - zaken die niet in de tastbare en meetbare werkelijkheid op zich zelf gegeven zijn, maar door mensen aan het bestaan worden toegekend en die het leven waarde geven.

\section{Toelichting}

De traditionele theologie gaat uit van 'openbaring', dat wil zeggen dat de religie, de ethiek, de riten, de geschriften en de theologie rechtstreeks door God zijn ingegeven (geïnspireerd) aan de profeten van de betreffende godsdienst. Het gevolg is dat daardoor ook de geloofsgemeenschap (kerk) en haar theologie, clerus, riten en kerkrecht, heilig, onaantastbaar en boven kritiek verheven worden: ze zijn immers de voortzetting van de geopenbaarde waarheid. Ook de bijbel wordt als een eenheid van verkondiging gezien die 'van kaft tot kaft' één boodschap zou verkondigen. Het moderne godsdienstwetenschappelijke onderzoek heeft echter ruimschoots uitgewezen dat ook religie door de eeuwen heen verandert en groeit en bestaat uit verschillende interpretaties 
en opvattingen van het Heilige, zoals dat wordt beleefd in verschillende tijdperken en culturen. De conclusie moet zijn dat er niet één absolute waarheid bestaat, maar dat elke tijd en cultuur op een eigen wijze en met een eigen interpretatie met het ondoorgrondelijke geheim van de goddelijke aanwezigheid omgaat en zo tot een eigen 'waarheid' komt. Alle uitspraken over 'boven' komen van 'beneden' (Kuitert). Interpretatietheologie staat tegenover openbaringstheologie.

\section{Overweging 2}

Daar moet men aan toevoegen, dat elke interpretatie een interpretatie van 'iets' is: van een fenomeen, een gebeurtenis, een manifestatie, een mens, een ontmoeting of een tekst kortom van zaken die zich aan ons voordoen. Deverschijnende fenomenen of feiten zijn misschien niet 'objectief' vast te stellen, zoals de postmoderne filosofen vaststellen, maar ze 'praten wel mee' (Ricoeur) in het interpretatieproces. Je kunt niet alles beweren over de werkelijkheid. Ons wereldbeeld bestaat niet uit pure 'constructie' of 'projectie'. De (voorlopige en momentele) waarheid ontstaat in een dialoog, een heen en weer, tussen object en subject (zie bijv. Bernstein 1983). Dat geldt ook voor een religieuze waarheid: religie interpreteert God, zoals men hem ervaart in de natuur, in mensen of in gebeurtenissen. En die interpretaties verschuiven in verschillende tijden en culturen. Uitspraken over 'boven' komen van 'beneden', maar ze pretenderen wel uitspraken te zijn over 'boven', althans over de mysterieuze en uitdagende Manifestatie, die zich aandient achter onze tastbare werkelijkheid!

\section{Overweging 3}

Geloof (in een god, de natuur, het lot of een ander houvast voor het leven) is niet in de eerste plaats een gevoel - laat staan een schlechthinniges Abhängkeitsgefühl (Schleiermacher) - maar een totaal interpretatiesysteem, dat het hele leven richting geeft en zowel het gevoel als het denken behelst. Het is een laatste en totaal vertrouwen in en respons op een Macht die ons omvat en inspireert. Religie is de allesomvattende omgang met het grote Mysterie van het bestaan in leer en leven, in handelingen en riten, en in toewijding en aanbidding.

\section{Overweging 4}

Religie kan men - met Clifford Geertz (1973:90) omschrijven als een 'symboolsysteem' of een 'cultureel systeem' dat men zowel van binnenuit (participerend) als van buitenaf (observerend) - in een zogeheten 'thick description' - kan beschrijven en interpreteren. Religies zijn symboolsystemen met een uitvoerig interpretatiekader (concepties, denkbeelden, verhalen, mythen etc.), een inspirerende motivatie en betrokkenheid (overgave, aanbidding, toewijding) en een omvattende ethiek gericht op het ultieme geheimenis en de uiteindelijke samenhang van de werkelijkheid waaraan mensen hun laatste zekerheden ontlenen. Religie is een 'ultimate concern' (Paul Tillich), datgene waarop we ons uiteindelijk met ons hele bestaan richten, waar we op vertrouwen en ons - vaak onvoorwaardelijk - aan overgeven. Men kan ook zeggen: religie is een ultiem vertrouwen in een proefondervindelijk waardevol gebleken interpretatie- en waardesysteem dat ons door de traditie wordt aangereikt, maar in de loop van de tijd ook verandert.

De overgang van het ene naar het andere interpretatiesysteem (of paradigmashift, zoals Thomas Kuhn [1962] dat noemt) verloopt voor de meeste mensen zeer moeizaam en met veel onbegrip en pijn. Dat geldt zeker ook voor de overgang van een openbaringsreligie, waarin alle zekerheden van ouds vast lagen in dogma's en geloofsbelijdenissen, naar een interpretatiereligie, waarbij men aansluiting zoekt bij een interpretatiesysteem dat past bij de eigen levensfilosofie en dat niet alleen voortbouwt op de eigen traditie, maar ook rekening houdt met de plausibiliteitstructuren van de eigen tijd en de effecten op de samenleving en het eigen leven (Tracy 1981:3-46).

\section{Overweging 5}

Religie als gerichtheid en reactie op een ultiem, inspirerend en uitdagend geheimenis heeft mensen door de eeuwen heen een houvast voor het leven gegeven, is een inspiratiebron voor persoonlijke en sociale betrokkenheid en ontwikkeling geweest, en heeft een samenhangende en samenbindende ethiek opgeleverd met een intrinsieke motivatie voor het persoonlijke en publieke leven.

De keerzijde is dat religieuze leiders en fanatici soms misbruik hebben gemaakt van de afhankelijkheid en goedgelovigheid van mensen. Dat hangt samen met de opvatting dat niet alleen het goddelijke geheimenis, maar ook de daarvan afgeleide religie, de kerk en de theologie als zodanig 'heilig' en 'onbetwistbaar' zouden zijn en deel zouden uitmaken van het goddelijke gezag in plaats van menselijke reactie daarop en vormgeving daarvan.

Er is echter geen absolute en onaantastbare uitleg van het goddelijk geheim, alsof God 'zichzelf zou uitleggen'. God manifesteert zich als een uitdagend 'geheimenis' dat wij eerbiedigen en aanbidden en waarop wij op verschillende wijzen kunnen reageren en reflecteren.

\section{Overweging 6}

Men kan dat ultieme geheimenis op verschillende manieren omschrijven en op verschillende 'plaatsen' zoeken. Het gaat niet om de abstracte (en onbewijsbare) vraag of 'God bestaat' - daarvoor is geen enkel bewijs of tegenbewijs te leveren - maar wie of wat we 'god' of het 'laatste houvast in het leven' noemen, omdat het zich als betrouwbare en een uiteindelijke en existentiële waarheid voor het leven aan ons - en ons voorgeslacht - heeft voorgedaan. Men kan het goddelijke zien in de creativiteit van de 'natuur' (zoals de natuurreligies doen), de toevalligheid van de 'evolutie' (zoals de evolutionisten doen), de grilligheid van het 'lot' (zoals veel praktisch ingestelde mensen doen), in de menselijke 'geest' (zoals humanisten doen) of in de regie van een bovennatuurlijke 'macht' of 'persoon' (zoals theïsten doen). 
Tegenwoordig is er ook sprake van 'ietsisme' ('Er moet wel iets zijn dat boven onze leefwereld uitgaat, maar dat heeft feitelijk weinig consequenties voor het leven') en 'symbolisme' ('Religie of religieuze riten zonder God' met spontane gevoelsuitingen bij evenementen of calamiteiten), maar dat zijn residuen van oude religieuze concepten en in het beste geval pogingen om vanuit een nulpuntsituatie religie opnieuw te doordenken en te beleven.

Deze verschillende interpretaties en oriëntaties roepen verschillende levensrichtingen en levensstijlen op. Men kan dat meer berustend of meer actief invullen en in een meer traditioneel religieus of een meer seculier kader beleven. Elke interpretatie heeft haar eigen 'mythologie'. Deze kan variëren van de mythologie van het leven als richtsnoer, het toeval als levenstragiek, de kracht van de menselijke geest, de onderwerping aan een bovennatuurlijke Macht tot aan het geloof in de Bevrijdende God die zich heeft gemanifesteerd in de gestalte van profeten en/of in de persoon en het optreden van Jezus.

\section{Toelichting}

De godsdienstfilosofie heeft zich veel te lang bezig gehouden met 'godsbewijzen', die altijd afhankelijk zijn van de voorafgaande premissen. Men kan ook uitgaan van dat wat mensen als 'goddelijk' interpreteren. Vandaar mijn voorkeur voor een 'interpretatietheologie': wie of wat noemen wij 'god' of 'heilig' of het 'laatste houvast' in het leven en waar zetten we ons ultieme vertrouwen op?

\section{Overweging 7}

Er zijn veel godsdiensten en zingevingssystemen op aarde, maar als men naar hun familiaire verwantschappen kijkt, zijn er enkele grote stromingen te herkennen.

Er zijn bijvoorbeeld natuurreligies in allerlei soorten die Moeder Natuur als bron van en norm voor het leven beschouwen. Men vindt ze zowel in zogeheten primitieve samenlevingen als ook in moderne natuurmystiek en in een - soms bijna cynisch - geloof in de toevalligheid van het alles en allen beheersende biologische evolutieproces.

Er zijn ook godsdiensten die het goddelijke lokaliseren in de (menselijke) geest. Men gelooft in de redelijkheid en/of de innerlijke zedenwet van de mens (Kant). Men ontmoet het goddelijke door door te dringen in het eigen bewustzijn, omdat onze geest deel uitmaakt van de absolute Geest.

Er is ook een combinatie van deze twee zienswijzen waarbij de geest (logos) van de mens en de natuur samenvallen, zoals bijvoorbeeld in de klassieke Stoa.

Verder zijn er de religies die van de veronderstelling uitgaan dat God hoog boven de natuur en de geschiedenis van de mensen troont in een verre hemel - zoals in het (late) jodendom, het christendom en de islam het geval is - en dat God de Schepper van het heelal en de absolute Heer van de geschiedenis is. Men ontmoet God door in aanbidding 'omhoog' te kijken.
Tenslotte is er ook een religieuze beleving die God ziet in de krachten van vernieuwing en herstel.

\section{Keuze voor een christelijke interpretatie}

In het vervolg kies ik voor de interpretatiegeschiedenis van het christendom die niet alleen een lange indrukwekkende geschiedenis binnen Europa en Amerika heeft gehad, maar ook van grote invloed is geweest op de ontwikkeling van grote delen van de wereld. Geboren, getogen, ingebed en opgeleid in de Nederlandse Hervormde variant van de protestantse interpretatiegeschiedenis als een - voor mij en vele generaties voor mij - overtuigende vorm van religie, heb ik mijn leven lang gezocht naar een eigentijdse wijze van geloven binnen deze christelijke traditie, zoals die is voortgekomen uit het oude Israël en gestalte heeft aangenomen in de bevrijdende kracht van Jezus, die we daarom de Christus zijn gaan noemen. Ik probeer daarom in het volgende - op mijn eigen wijze en vanuit mijn achtergrond - deze interpretatiegeschiedenis voort te zetten binnen het kader van een geseculariseerd Europa dat steeds meer lijkt te vervreemden van haar culturele wortels.

\section{Israël Overweging 8}

Ook de bijbel bestaat uit verschillende interpretaties èn herinterpretaties van vroegere interpretaties - van het goddelijke geheim, want ook de bijbel is in principe 'mensenwerk': reflectie en reactie op het ondoorgrondelijke Geheimenis. Onze eigen(tijdse) interpretatie van bijbelteksten moet er bovendien rekening mee houden dat teksten - zoals Ricoeur zei - weerbarstig zijn en weerstand kunnen bieden aan onze interpretatie, zodat we voortdurend in gesprek moeten blijven met de teksten van de bijbel en met de exegeten. Op grond van deze dialoog met de bijbel en de bijbelwetenschappers kan men verschillende interpretatielagen in de bijbel onderscheiden.

In het oude Israël heeft er tussen 700 en 400 voor Christus een fundamentele omslag plaats gevonden van een natuurgodsdienst met meerdere goden (Baäl, Astarte, Jahwe etc.) die de natuur en haar verschijnselen representeren, naar het monotheïsme van de ene God die boven de natuur en de geschiedenis staat. Een dergelijke kentering van naturalistisch polytheïsme naar monotheïsme vond er in die tijd ook in andere culturen plaats, zodat Karl Jaspers van een 'Achsenzeit' in de geschiedenis is gaan spreken. Ook in Griekenland was er in die periode in de filosofie een zoektocht naar het ene grote Beginsel van de werkelijkheid.

In het klassieke jodendom, christendom en de islam is men daarom van één transcendente en onvergelijkbare Macht 'achter' of 'boven' de natuur en de geschiedenis als goddelijke inspiratiebron uitgegaan en men heeft die als een 'persoonlijke' Macht geïnterpreteerd en ervaren. Jahwe/God/Allah is de Schepper van de wereld, de Heer van de geschiedenis en de persoonlijke Leidsman van de gelovigen. 


\section{Overweging 9}

De God van Israël is echter niet alleen de Schepper van de wereld en de mensheid en de Regisseur van de geschiedenis, maar vooral ook de grote Bevrijder en Verlosser. Niet alleen de garant van het bestaan, zoals dat bekend is uit de meeste andere godsdiensten, maar ook de Vernieuwer en Uitdager van de geschiedenis. Hij (of $\mathrm{Zij}$ ) trekt mensen weg uit de beklemming van het verleden en lokt ze steeds verder de toekomst in. Verder blijft deze God niet verborgen in een verre hemel, maar hij manifesteert zich door en in mensen. Niet in de natuur of in het lot, maar uitdrukkelijk in mènsen: profeten, zieners, de 'Knecht des Heren' van Deuterojesaja en zo meer, die zijn lokroep interpreteren en verwoorden. Hij wordt Immanuël genoemd: God mèt ons. Het gaat om een God met een 'menselijk gezicht', die mensen ook aanspreekt als verantwoordelijke personen, zodat hij een 'verbond' met hen kan sluiten. Adam, Eva, Abraham, Sara, Izaäk en Jacob, maar ook Mozes, Saul en David en zelfs de profeten van het Oude Testament zijn herkenbare mensen, ook al zijn ze in feite meer romanfiguren dan historische persoonlijkheden. Er is met die mensen te praten en zij kunnen met hun God 'praten en onderhandelen'. De psalmen zijn er een voorbeeld van, maar ook veel verhalen laten zien hoe deze God met mensen en mensen met hun God omgaan. Niet voor niets staat het verbond tussen God en mens centraal in de religie van het Oude Testament. En ook de wetten hebben een humane kant als men ze vergelijkt met de omringende wetgeving waarvan ze grotendeels zijn afgeleid. Het begrip gerechtigheid krijgt een bijzondere inhoud. Kort en goed: het gaat in het Oude Testament om de ene God, de Bevrijder en Uitdager, met een menselijk gezicht, die mensen serieus neemt en opkomt voor het recht van de zwaksten.

\section{Overweging 10}

Opvallend voor deze vorm van godsdienst is het feit dat ze steeds andere gestalten heeft aangenomen in de loop van haar geschiedenis. De Geest van God - of de 'invloed' van God op mensen - schept kennelijk voortdurend nieuwe gestalten binnen nieuwe culturele situaties.

Ontstaan als een variant van het Baälisme, is het Jahwisme uitgegroeid tot de verering van de ene God: Jahwe, de Heer van de geschiedenis en de bevrijder van Israël, zodat er in de tijd van de ballingschap een nieuwe gestalte kon opbloeien van het oude geloof in Jahwe met een eigen canon (de Thora) en een eigen ethiek. Na de verwoesting van de tempel in het jaar 70 heeft het jodendom een eigen ontwikkeling in verschillende gestalten doorgemaakt.

In het Nieuwe Testament schept de Geest van God een nieuwe gestalte van Gods handelen in de figuur van Jezus en later krijgt het christelijk geloof eigen vormen in de theologie van Paulus, de synoptici en Johannes.

In de middeleeuwen manifesteert het christendom zich als een eenheidsgodsdienst die alle tegenspraak smoort en ketters vervolgt en verbrandt.
In de tijd van de reformatie ontstaan er verschillende varianten van geloofsbeleven en geloofsleer en in onze tijd verschijnt het oude geloof in talloze denominaties en gemeenschappen.

Die ontwikkeling is inherent aan de wijze waarop mensen het goddelijke geheim interpreteren en de Geest gestalte aanneemt in verschillende tijden en culturen. Die gang van zaken is onomkeerbaar.

\section{Toelichting}

In de geschriften van Jesaja en vooral Jeremia wordt God gezien als de Heer van de geschiedenis die hoog boven het aardse gedoe uit troont en zo de wereld regeert. Ook de vijandelijke volken zijn werktuigen in zijn hand om Israël te straffen en later te bevrijden. In Deuterojesaja komt echter voor het eerst ook de gestalte van de lijdende Knecht tevoorschijn als een nieuwe gestalte van de hoge en grote God. Daar ziet men hoe de grote en verheven God samentrekt en verschrompelt tot de lijdende Knecht die - als het ware - in de geschiedenis kruipt en de klappen van het onheil opvangt. Hij wordt de Bevrijder van binnen uit. De Kompaan in het menselijk gevecht tegen zonde en lot. De grote God maakt zich klein en manifesteert zich op menselijk vlak - dat wil zeggen: in mensen. Voor christenen heeft God zich vooral 'klein' gemaakt in de mens Jezus en in zijn volgelingen. God is niet langer de Grote Regisseur van het wereldgebeuren, maar de bijna onhoorbare Medestrijder voor het behoud van de mensheid.

Een dergelijke contractie of samentrekking van God heeft eigenlijk ook al plaats gevonden bij de schepping, toen de Schepper ruimte maakte voor de wereld, de natuur, de mens en de geschiedenis. ${ }^{1}$ Het christelijk geloof berust op een God die zich heeft klein heeft gemaakt en daardoor ruimte heeft gemaakt voor de evolutie van de natuur en de ontplooiing en verantwoordelijkheid van mensen.

\section{Jezus}

\section{Overweging 11}

Het christendom is een dochter van Israël. De joodse voorstellingen worden door Jezus opgepakt en geherinterpreteerd en gerevitaliseerd (Theissen 2001). De joodse ethiek, met zijn humane kanten, wordt bijvoorbeeld door Jezus nog veel radicaler op scherp gezet. De wet wordt geradicaliseerd tot het grote liefdesgebod - met tegelijkertijd een grote tolerantie en mededogen voor 'zondaars'. 'Deze dubbele radicalisering van het ethos, zowel in de richting van een consequentere strengheid, alsook in de richting van een vergevingsgezindheid die alles overtreft, is de ontplooiing van mogelijkheden die aanwezig waren in de joodse traditie' (Theissen 2001:58 e.v.).

Daar kan men aan toevoegen, dat Jezus bij uitstek het menselijk gezicht van God representeert. Hij heeft God niet alleen een stem en een gezicht gegeven, maar hem - om zo te 1.Zie de interpretatie van de Joodse zimzum door Hans Jonas, 1984, Der Gottesbegriff nach Auschwitz. 
zeggen - ook handen en voeten gegeven. Zelfs zo sterk, dat men later kon zeggen dat God in de gestalte van Jezus mens is gewòrden! Men kan ook zeggen dat God zich afhankelijk heeft gemaakt van deze menselijke en kwetsbare mens. Jezus vertegenwoordigt niet alleen Gods menselijkheid, hij gedraagt zich ook uiterst humaan tegenover mensen en hij zet zich in voor verworpenen. Dat geldt zowel 'zondaars' als 'zieken' en 'uitgestotenen'. Jezus vertegenwoordigt geen abstract godsbegrip, maar een actieve dynamische goddelijke energie die zich openbaart in de genezing van zieken, de vergeving van zondaars en het contact met gediscrimineerden, en dat wordt gesymboliseerd in de opstanding in een nieuw leven. Verder sluit Jezus weer aan bij de universalistische tendensen van de grote profeten van het Oude Testament die sinds de terugkeer uit de ballingschap waren ingeruild voor een benauwd particularisme. Maar en dat is de herinterpretatie - hij gaat niet uit van Gods alles overheersende almacht die zelfs Nebukadnezar in zijn hand heeft, maar hij zet mensen in de grensoverschrijdende ruimte van Gods alles overheersende liefde.

\section{Overweging 12}

In het optreden van Jezus is God niet zozeer de Heer van de geschiedenis die 'alle ding regeert', maar meer de Participant in onze geschiedenis die meewerkt - en dat wil zeggen: meelijdt en meestrijdt - om alle dingen ten goede te laten keren. Hij is voor christenen de uiteindelijke Immanuël: God met ons. Opstanding in een nieuw leven is een betere omschrijving van Jezus' invloed dan Heer van de geschiedenis. Hij representeert en bewerkt een nieuw leven door het lijden heen. Zo geeft hij een nieuwe zin aan het bestaan.

\section{Overweging 13}

Reeds binnen het Nieuwe Testament zijn er verschillende interpretaties aanwezig van de als fundamenteel ervaren ontmoeting met Jezus. Paulus heeft een gezaghebbende vertolking van zijn ervaring met Jezus op de weg naar Damascus (en alles wat daaraan vooraf is gegaan en wat er op is gevolgd) gegeven in zijn brieven aan de Galaten, de Korintiërs en de Romeinen; de synoptici hebben een eigen verhaal (ieder met zijn eigen nuances) over Jezus verteld; Johannes en de Brief aan de Hebreeën hebben er later hun eigen interpretaties aan toegevoegd. Dat geeft het christendom mogelijkheden voor een grote pluriformiteit die echter door de kerk van het begin af aan in een eenheidsstreven is gesmoord.

\section{Christendom Overweging 14}

Het christendom - in een mengvorm van Paulus, Johannes, de synoptici en de Brief aan de Hebreeën - is al spoedig een huwelijk aangegaan met het Hellenisme. Men heeft het geloof verwoord in de taal van de filosofie van die tijd met een absolute prioriteit van de 'geestelijke wereld' boven de 'materiële wereld'. De religiositeit van het christelijk geloof is verder beïnvloed door de mysteriegodsdienstigheid en heeft zo een eigen - katholieke - gestalte aangenomen met de eenheid van taal, ambt, sacramenten en bijbel.

\section{Overweging 15}

Het katholieke christendom heeft de God van Israël in drie 'gestalten' vereerd die tegelijk transcendent en immanent zijn: als Schepper van de werkelijkheid, als Bevrijder die zich in de geschiedenis heeft gemanifesteerd als God met ons (Immanuël) en als Bezieler van mensen. Binnen de hellenistische wereld hebben christelijke theologen dat samengevat in de formule van de drie-enige God: Vader, Zoon en Heilige Geest, die als drie personen (hypostasen) één wezen vormen. Die klassieke drieslag heeft aan het christendom een geweldige ruimte voor ontwikkeling gegeven.

\section{Overweging 16}

Omdat theologie - het denken over het grote mysterie van God - mensenwerk is, kan men in een moderne setting, als hedendaagse vertolking van het bijbelse geloof, beter niet spreken van God als één Wezen in drie Personen, maar van één God die zich op drie verschillende wijzen in onze werkelijkheid manifesteert. De vertaling van het Griekse hypostasis (gestalte) in het Latijnse persona heeft de drie-enige God teveel tot drie zelfstandige personen gemaakt. Vooral de Heilige Geest kan men beter als de 'invloed van God' dan als 'persoon' omschrijven. Daarom spreek ik liever van de ene God die onze werkelijkheid heeft geschapen en er zijn 'creativiteit' of 'energie' ingelegd heeft, die mensen inspireert en bezielt tot aanbidding, engagement en inzet voor de wereld en de medemens door zijn Geest, en die - op een unieke wijze, die echter andere mogelijkheden niet uitsluit - in de persoon van Jezus een bijzondere en moeizame inwoning in onze werkelijkheid is aangegaan om die te veranderen en te verbeteren. Dat zijn drie fundamentele relaties van God met de wereld. De volgorde is: Vader (Schepper), Geest (Inspirator van mensen) en de historische gestalte van de Zoon in het christendom. Dat is een vorm van pneumatheologie die ruimte schept voor groei en ontwikkeling, voor de inbreng en eigen verantwoordelijkheid van mensen en voor andere godsdiensten en culturen.

\section{Toelichting}

Oude voorstellingen als de triniteitsleer, de tweenaturen doctrine en de verzoeningsleer moeten steeds weer gedeconstrueerd worden om ze daarna op een nieuwe wijze te kunnen interpreteren in nieuwe tijden en culturen. Dat geldt niet alleen voor de theologische reflectie maar ook voor de kerken, al zijn kerken daarin als regel zeer terughoudend en bedeesd, omdat de heilsverwachtingen van hun leden samenhangt met de overgeleverde geloofsovertuigingen.

\section{Overweging 17}

Eigenlijk zou een pneumatheologie nog een stap verder moeten gaan en God niet moeten omschrijven als een identiteit buiten of boven onze werkelijkheid, maar als de 'Geest' die zich op verschillende wijzen in onze wereld manifesteert: als 
Scheppingsenergie (die niet vanzelfsprekend samenvalt met wat wij natuur noemen!); als Begeleider en Inspirator van de menselijke geschiedenis in de gestalte van profeten en zieners (mènsen!) en vooral als Bevrijder. De Geest gaat niet van God de Vader uit, maar God is Geest die zich in verschillende relaties tot de wereld en de mensheid manifesteert. Daar moet bij opgemerkt worden dat de inwerking van Gods Geest tegelijk ruimte laat voor een eigen ontwikkeling van de natuur en de menselijke geschiedenis. Bij de schepping heeft de goddelijke Schepper zichzelf ingeperkt tot 'faciliterende Macht' die niet als een Pantokrator alles beheerst en bepaalt, maar 'mogelijkheden schept', zodat zowel de natuur als de mensheid zich op een eigen wijze kunnen ontplooien. Op deze wijze is God - op een transcendente wijze - immanent in de wereld aanwezig.

De Geest van God is voor christenen op een bijzondere en unieke wijze aanwezig in het optreden van Jezus. Hij is Pneumatofoor: de unieke Drager en Werktuig van de goddelijke Geest in de wereld - zelfs na zijn dood. Dat vraagt mogelijk om een nieuwe doordenking van een soort christelijk unitarisme, of unitarisch pluralisme, waarbij de eenheid van God voorop staat, ook al werkt de goddelijke Geest op verschillende niveaus en op verschillende wijzen en door meerdere middelen en personen op onze wereld in.

\section{Toelichting}

Voor het standpunt dat ik tot nu toe innam kan ik het beste verwijzen naar mijn De stem van de Roepende (2005) en Sporen van de verborgen God (2010). Daar is God een 'transcendente persoon' boven de geschiedenis van de natuur en de mensen, wiens invloed (de Geest) inwerkt op mensen. $\mathrm{Nu}$ formuleer $\mathrm{ik}$ het nog wat radicaler door te stellen dat men zich God niet moet voorstellen als een entiteit of persoon boven en buiten onze werkelijkheid (in de hemel!), maar als de Geest die zich op verschillende wijzen in onze werkelijkheid manifesteert: in de natuur als 'scheppende energie'; in de geschiedenis als inspiratiebron die zich presenteert in de gestalte van personen en vooral in de persoon van Jezus die we de Christus noemen. Zo begeleidt hij mensen op een rechtvaardige, liefdevolle en hoopvolle wijze en zo daagt hij als bevrijdende inspirator de geschiedenis uit. Daardoor heeft God een menselijk gezicht gekregen. God is niet langer de alles bepalende macht in de natuur en de geschiedenis, maar de Energie, de Uitdager, die de natuur en de mensen ruimte geeft om zich op een eigen pluriforme - manier te ontplooien.

\section{Overweging 18}

$\mathrm{Nu}$ een metafysica, die het zijn op een dwingende (Vattimo) en heersende wijze gelijkstelt met objectiviteit, plaats lijkt te moeten maken voor een metafysica van het worden of de beweging (Whitehead), die (soms) meerdere interpretaties uitlokt, verandert niet alleen de interpretator voortdurend in het interpretatieproces, maar is ook het interpretandum - het zijn, of de werkelijkheid - voortdurend in beweging. Dat geldt ook voor God die elke morgen weer nieuw is en reageert op onze wereld. Wie God is in zichzelf kan men niet zeggen. Hij is de verborgen God, een 'zwart gat' achter of boven de door ons gekende werkelijkheid, een 'vreemde' kracht die 'gebeurt' en zich als een 'Vreemdeling' (Kearney) in verschillende gestalten in de geschiedenis manifesteert en handelt, die ons uitnodigt, roept en reacties van ons uitlokt. En wij zijn voortdurend in dialoog en relatie met dat Gebeuren. De werkelijkheid en de waarheid zijn vloeiend geworden ... Misschien is daarom 'bevrijdende creativiteit' die ruimte geeft aan de natuur, de geschiedenis en aan individuele mensen wel de beste aanduiding voor de God van de bijbel.

\section{Overweging 19}

In vorige eeuwen stond de absolute waarheid en onaantastbaarheid van het christendom voor het westerse denken vast. In een mondiale setting met veel verschillende culturen en religies zal men moeten erkennen dat een (geloofs) waarheid voor de gelovigen wel absoluut is, maar niet universeel hoeft te zijn (zoals opperrabbijn Jonathan Sacks uit New York het formuleerde). Het gaat niet om één 'abstracte' waarheid die altijd en overal geldig is, maar om 'waarheid voor mijn leven'. Het is een waarheid die gefundeerd is in een existentiële relatie en berust op vertrouwen, maar die op verschillende tijden en op verschillende plaatsen en door verschillende mensen anders geformuleerd en beleefd wordt.

Een pneumatheologie geeft ruimte voor zowel religies die zich richten op de scheppingskracht van de natuur alsook op religies die focussen op de goddelijke inwerking op de menselijke geest, en religies die God zien als de Bevrijder en Vernieuwer. Missiologie is daarom niet 'anderen van mijn gelijk overtuigen', maar 'samen met anderen je inzetten voor het voortbestaan en verbeteren van de wereld'.

\section{Overweging 20}

In een door wetenschap beheerste wereld waarin de prioriteit van de materiële wereld het steeds meer wint van de 'geestelijke wereld' zou men het ultieme geheim en de scheppende energie van de werkelijkheid het beste kunnen omschrijven als een 'immanente transcendentie' en een 'bevrijdende creativiteit'. Dat wil zeggen: een uiteindelijk onverklaarbare macht of energie binnen de kaders van de ervaarbare werkelijkheid die we aanduiden als 'heilige Geest'. Die Macht manifesteert zich in het feit dat er iets is en niet niets (of: scheppingsmacht), in het feit dat de dode materie op ondoorgrondelijke wijze op een hoger plan is getild, en in het bewustzijn van mensen dat het leven kan ordenen, verklaren en genieten. Die Geest heeft vooral gestalte aangenomen in de profeten en zieners van het Oude Testament en in Jezus en zijn volgelingen. De Geest heeft zich in onze geschiedenis 'gepersonifieerd'. Daardoor is het christendom een bevrijdende en emanciperende factor in de wereldgeschiedenis geworden. Mensen en werelden worden - door lijden en dood heen - herschapen in een nieuw bestaan.

Zo ontstaat er een nieuwe creatieve theologie van de schepping: een proces dat heeft geleid tot het verschijnen van 
de mens, waarbij de goddelijke Kracht zich uiteindelijk heeft verbonden met de menselijke existentie.

\section{Overweging 21}

Het christendom heeft met zijn voorstelling van een lijdende Jezus een vraagteken geplaatst bij het algemeen menselijke dogma van de almacht van God. Berkhof introduceerde het begrip 'weerloze overmacht' (Berkhof 1973:141-148) waarbij Gods 'zwakte' zijn kracht is. Moltmann (1972) sprak zelfs van de Gekreuzigte Gott. Als God ingaat in de geschiedenis maakt hij zich 'klein' en wordt hij participant in een strijd tussen goed en kwaad en ontmoet hij machten die tegen zijn wil ingaan. Ik sluit mij aan bij Hans Jonas (1984) die nog een stap verder gaat als hij zegt dat God bij de schepping al (veel) macht uit handen heeft gegeven ten gunste van de ontwikkeling van natuur en mensen. Het is de God die een 'verbond' sluit met mensen en ruimte biedt voor een eigen ontwikkeling. En in dat verbond worden - om zo te zeggen - de taken tussen God en mens verdeeld. Men kan dat een theologie van de kenosis noemen: 'God doet afstand van zijn soevereine transcendentie' (Caputo \& Vattimo 2006).

\section{Overweging 22}

De theologie moet afstand nemen van de - aan het Griekse denken ontsproten - 'al-woorden' voor God: almachtig, alwetend, alziend, alomtegenwoordig en zo meer. Dat geldt ook voor de 'on-woorden', zoals onveranderlijk, onafhankelijk. Dat zijn begrippen die de christelijke dogmatiek heeft gebruikt om het geloof in God te omschrijven, te definiëren en te verdedigen in een hellenistische wereld. Die omschrijvingen zijn meegegaan de middeleeuwen in en hebben zich kunnen handhaven in de reformatie. Zie artikel 1 van de Nederlandse geloofsbelijdenis.

Wij moeten ons realiseren dat de God van de bijbel zich heeft beperkt en kwetsbaar heeft gemaakt in de daad van de schepping en in de inwoning in de geschiedenis. Daarvoor zijn andere (filosofische) omschrijvingen nodig. In het verleden heb ik gepoogd om de procesfilosofie van Whitehead daarvoor te gebruiken. Theo de Boer (2013) gebruikt, bijvoorbeeld, termen van Pascal en Levinas. Het gaat er om de beweeglijkheid en het mede lijden van de verborgen God in de geschiedenis onder (moderne) woorden te brengen in een wereld die een absolute prioriteit geeft aan de empirische, tastbare en meetbare werkelijkheid. De gebruikelijke weg is die van de antithese: het geloof houdt vast aan de oude voorstellingen en begrippen, zoals die vanaf het begin van het christendom gangbaar zijn geworden en stelt zich tegenover het gangbare wereldbeeld. Ik kies voor de weg die het oude geloof probeert uit te drukken in de terminologie van het moderne denken, omdat ik vermoed dat er in de eenentwintigste eeuw een fundamentele omdenking van ons hele interpretatieveld bezig is plaats te vinden. En de christelijke religie bevat zoveel waardevolle inzichten en uitdagingen en biedt zo'n diepgaande relatie met de liefdevolle en barmhartige God dat het de moeite waard is de hele christelijke traditie vanuit moderne inzichten nog eens te overdenken en op een nieuwe manier te herinterpreteren.

\section{Persoonlijk leven als roeping Overweging 23}

Leven als christen is niet in de eerste plaats een mystieke ervaring of een extreem zondebesef, maar het moderne religieuze grondbesef is meer (1) een diep gevoelde eerbied voor het geheim van het leven waar we traditioneel de naam van God aan geven met een intense verwondering over de weidsheid en de schoonheid van de schepping - inclusief de uitdagingen die zowel in de natuur als in de geschiedenis liggen, (2) een even grote verbazing over de manier waarop wij mensen (en wij zelf) - wetend of onwetend, bewust of onbewust, opzettelijk of onopzettelijk-metdescheppingende medemensen omgaan met daaraan verbonden een besef van schuld, tragiek en machteloosheid, (3) een intens vertrouwen in de ondoorgrondelijke liefde van God de Bevrijder, en op grond daarvan (4) een diepgevoeld roepingsbesef om de wereld weer aan de scheppingsbedoelingen aan te passen als een respons op de stem van de Roepende.

\section{Overweging 24}

De traditioneel christelijke nadruk op de menselijke zonde als persoonlijke schuld is eigenlijk te simpel. Het menselijk bestaan wordt evenzeer gekenmerkt door het toeval van het lot (de gegevenheid van de feitelijke omstandigheden), de structuren waarin mensen verstrengeld zijn en de mogelijkheden van de vrijheid en de verantwoordelijkheid die men neemt. Er moet dus veel meer aandacht komen voor de tragiek van het bestaan waarbij de mens klem komt te zitten tussen de toevallige omstandigheden en structuren en zijn eigen verantwoordelijkheid. De mens is niet van nature slecht, zoals de traditionele zondeleer stelt, maar de mens is als persoon zwak, ambivalent en vaak machteloos. Bevrijding is niet alleen vergeving van zonden, maar ook verlossing uit de klem van het bestaan en de mogelijkheid van nieuwe kansen. De theologie zou een verzoeningsleer moeten ontwerpen die ingaat op onpersoonlijke schuld en de verzoening van zonden die men onwetend en/of uit onmacht heeft begaan.

In de tragedies van Sophocles en Euripides vindt er een hopeloze strijd plaats van de hoofdfiguren tegen hun al of niet door de goden bepaalde lot waaraan zij niet kunnen ontkomen. Ze moeten zich er in schikken. Ze kunnen weerstand bieden, maar ze kunnen niet aan hun lot ontkomen. Tegenwoordig hebben wij meer oog voor de structuren waarin wij gevangen zitten en die ons soms dwingen tot daden die we eigenlijk niet zouden willen begaan. Dat geldt voor de soldaat in oorlogstijd evenzeer als voor de burger die gevangen zit in economische en politieke structuren. Hoe bevrijdend is het christelijk geloof voor mensen die klem zijn komen te zitten in hun situatie?

\section{Overweging 25}

Misschien kan de middeleeuwse monnik Petrus Abaelardus (1079-1142) ons op dit punt verder helpen. Hij vatte de 
kruisdood van Jezus op als een teken van Gods onvoorstelbaar grote liefde voor mensen. Het is een liefde die als een vurige vlam op de mensheid gericht staat om de dikke ijslagen van de zonde en de schuld - en daar kunnen we de beklemming van het lot of de onvermijdelijkheid van de collectieve tekortkomingen aan toevoegen - te doen smelten en die mensen probeert tot een nieuw leven te wekken. Jezus wekt immers door zijn opofferende gezindheid wederliefde, zodat mensen weer in de goede relatie tot God komen te staan. Bij Abaelardus is het offer van Christus niet op God gericht, zoals bij Anselmus, de oudere tijdgenoot van Abaelardus, maar juist op de mensheid. Mensen van alle tijden kunnen zich warmen aan deze liefde en zo andere mensen worden. Verzoening geschiedt niet door voldoening, zoals bij Anselmus (en zondag 5 en 6 van de Heidelbergse Catechismus), maar door vergeving en vooral door bevrijding en verandering. God wendt zich in zijn overmachtige liefde tot de mens en de mens wordt daardoor aangeraakt en gaat zich op God en een nieuw leven richten. De activiteit van God trekt de mens weg uit de spanningen en de tragiek van zijn leven. Zo krijgen we ruimte en een uitgestoken hand als het mis gaat. Maar dan moeten we die hand wel grijpen ...

\section{Kerk als netwerk van interpretatiegemeenschappen Overweging 26}

Vanaf het ontstaan van het christendom heeft de eenheid van de kerk centraal gestaan en heeft men afwijkingen (ketterijen!) bestreden. Het ging om de eenheid van de bijbelse canon, de eenheid van ambt, de eenheid van leer (geloofsbelijdenis) en de eenheid en de heiligheid van het instituut (una sancta ecclesia catholica). Die eenheid werd voor het eerst doorbroken in 1054 door de splitsing in een oosterse en westerse kerk en later in de tijd van de reformatie (vanaf 1517), waarbij eerst nationale kerken ontstonden en er zich vervolgens naast de nationale kerken talloze denominaties vormden rondom geloofsthema's. De oecumenische beweging van de vorige eeuw is in feite mislukt, ondanks enkele spectaculaire kerkfusies. Pluriformiteit is - ook voor kerken-een onstuitbare ontwikkeling. In de toekomst zullen kerken zich plaatselijk en regionaal ontwikkelen rondom 'scholen' of 'interpretatiegemeenschappen' waar het geloof op een eigen wijze wordt geleerd, gevierd en in praktijk wordt gebracht. Ik spreek van 'scholen' om te voorkomen dat geloofsgemeenschappen al te individualistisch en heretisch worden. Sommige van deze gemeenten zullen op de traditionele wijze vorm geven aan hun geloof en anderen zullen naar nieuwe vormen en nieuwe formuleringen zoeken. Ze zullen in de toekomst waarschijnlijk niet meer in uniforme eenheidsinstituten zijn georganiseerd, maar in veel lossere 'netwerkorganisaties' die elkaar steunen, maar geen 'belijdenisdwang' meer opleggen. Wat mij betreft hoop ik dat ze geworteld blijven in de bronnen rondom Jezus (het Nieuwe Testament) die gerevitaliseerd worden voor nieuwe generaties.

\section{Erkenning}

Ik ben intussen 83 jaar en niet meer zo actief als voorheen ... Professor Johan Buitendag heeft mij een jaar geleden gevraagd een samenhangend artikel van mijn theologisch werk te schrijven. Hij wilde dat in het Engels vertalen. $\mathrm{Na}$ een lange reis door kerk en theologie is dit artikel een soort set van laatste overwegingen geworden voor de volgende generaties theologen. Vanuit een snel veranderd verleden!

\section{Tegenstrijdige belangen}

De auteur verklaart geen financiële of persoonlijke belangen te hebben die hem ongepast kunnen hebben beïnvloed bij het schrijven van dit artikel.

\section{Literatuurverwijzingen}

Berkhof, H., 1973, Christelijk geloof, Nijkerk, Callenbach.

Bernstein, J., 1983, Beyond objectivism and relativism: Science, hermeneutics, and praxis, Oxford University Press, Oxford.

Boer, Th. de \& Groot, G., 2013, Religie zonder God: Een dialoog, Reeks Oratio, Sjibbolet, Amsterdam.

Caputo, J.D. \& Vattimo, G., 2006, After the death of God, Columbia University Press, New York.

Dingemans, G.D.J., 2005, De stem van de Roepende, Kok, Kampen.

Dingemans, G.D.J., 2010, Sporen van de verborgen God, Kok, Kampen.

Geertz, C., 1973, The interpretation of cultures, Basic Books, New York.

Jonas, H., 1984, 'Der Gottesbegriff nach Auschwitz: Eine jüdische Stimme', in O. Hofius (Hrsg.), Reflexionen finsterer Zeit: Zwei Vorträge von F. Stern und H. Jonas, pp. 61-84, Mohr Siebeck, Tübingen.

Kuhn, T., 1962, The structure of scientific revolutions, University of Chicago Press, Chicago.

Moltmann, J., 1972, Der gekreuzigte Gott, Kaiser, München.

Theissen, G., 2001, De godsdienst van de eerste christenen: Een theorie van het oerchristendom, Agora, Averbode.

Tracy, D., 1981, The analogical imagination: Christian theology and the culture of pluralism, Crossroad, New York. 